CZASOPISMO INŻYNIERII LĄDOWEJ, ŚRODOWISKA I ARCHITEKTURY JOURNAL OF CIVIL ENGINEERING, ENVIRONMENT AND ARCHITECTURE

JCEEA, t. XXXIV, z. 64 (3/I/17), lipiec-wrzesień 2017, s. 259-270, DOI: 10.7862/rb.2017.120

\author{
Lukasz KRA WCZYK \\ Michał GOŁDYN ${ }^{2}$ \\ Tadeusz URBAN ${ }^{3}$
}

\title{
O NIEDOKŁADNOŚCIACH SYSTEMÓW CYFROWEJ KORELACJI OBRAZU
}

\begin{abstract}
Celem niniejszego opracowania jest omówienie niedokładności pomiarowych systemu Aramis. Ze względu na złożoność zagadnienia trudno jest znaleźć rozwiązanie ogólne. Do celów aplikacyjnych stosowana jest metoda polegająca na porównywaniu wielu zdjęć przedstawiających jeden stan powierzchni. W artykule zaprezentowano analizę niedokładności dla pola pomiarowego $1250 \times 1100 \mathrm{~mm}$. Rozrzut wyników rejestrowany przez system Aramis jest miarą błędu pomiaru. Stwierdzono, że odczyty z map odkształceń obarczone są znacznym błędem w stosunku do wartości powodujących zniszczenie betonu. Jednocześnie stwierdzono dobrą dokładność wyznaczenia zmiany długości odcinków pomiarowych, co umożliwia precyzyjne wnioskowanie o zmianach szerokości rozwarcia rys. Wskazano jak szukać szerokości rozwarcia rys, aby osiągnąć zbieżność z wynikami pomiarów prowadzonych tradycyjnie (wzrokowo). Przeprowadzono dyskusję dotyczącą wpływu wielkości podziału powierzchni na otrzymaną szerokość rys.
\end{abstract}

Słowa kluczowe: system korelacji obrazu, błąd pomiaru, szerokość rys, badania eksperymentalne

\section{Wprowadzenie}

Niniejszy artykuł ma na celu przybliżyć tematykę związaną z szacowaniem wielkości błędów z jakimi trzeba się liczyć korzystając z systemów cyfrowej korelacji obrazów. Przedstawiona analiza została przygotowana dla pola pomiarowego $1250 \times 1100 \mathrm{~mm}$. Materiał prezentowany w niniejszym artykule powstał podczas badania wsporników żelbetowych przeprowadzonych w Katedrze Budownictwa Betonowego Politechniki Łódzkiej. Na wielkość błędów mają wpływ: wielkość pola pomiarowego, niedokładności uśredniania i obliczania wyników przez oprogramowanie, zmiany oświetlenia podczas badania, szum

\footnotetext{
1 Autor do korespondencji / corresponding author: Łukasz Krawczyk, Politechnika Łódzka, Katedra Budownictwa Betonowego, al. Politechniki 6, 90-924 Łódź, lukasz.krawczyk@p.lodz.pl

2 Michał Gołdyn, Politechnika Łódzka

3 Tadeusz Urban, Politechnika Łódzka
} 
matryc $\mathrm{w}$ aparatach, ustawienie aparatów względem powierzchni, jakość obiektywów i sposób naniesienia deseniu na mierzoną powierzchnię.

Pomiary wykonywane za pomocą systemu cyfrowej korelacji obrazów możliwe są dzięki wykonaniu zdjęć powierzchni podczas badania. Na podstawie porównania zdjęcia dla danego obciążenia ze zdjęciem referencyjnym możliwe jest ustalenie przemieszczeń wybranych punktów na powierzchni. Na tej podstawie mogą być obliczane odkształcenia. Aby jednak taka analiza była możliwa system dzieli powierzchnię pomiaru na pola o ustalonej wielkości nazywane fasetkami. Standardowa fasetka charakteryzuje się wymiarami $21 \times 21$ pikseli. Drugą wartością charakterystyczną dla podziału jest odległość pomiędzy środkami sąsiadujących ze sobą fasetek. Wartość zalecana wynosi 18 pikseli.

Tabela 1. Wpływ wielkości fasetek na liczbę punktów obliczeniowych

Table 1. Influence of facets size on calculation points number

\begin{tabular}{|c|c|c|c|}
\cline { 2 - 4 } \multicolumn{1}{c|}{} & Wymiar fasetki & $\begin{array}{c}\text { Odległość pomiędzy } \\
\text { fasetkami }\end{array}$ & $\begin{array}{c}\text { Punkty } \\
\text { obliczeniowe }\end{array}$ \\
\cline { 2 - 4 } \multicolumn{1}{c|}{} & piksel & piksel & sztuk \\
\hline zagęszczona & $15 \times 15$ & 12 & 7145 \\
\hline typowa & $21 \times 21$ & 18 & 3364 \\
\hline rozrzedzona & $45 \times 45$ & 35 & 789 \\
\hline
\end{tabular}

Zagęszczania fasetek wpływa na wyniki w sposób analogiczny do zagęszczania siatki w modelu obliczeniowym metody elementów skończonych. Dla unaocznienia tego zjawiska przedstawiono przykład na podstawie wspornika E - II. Wpływ wielkości fasetek na liczbę punktów został pokazany w tabeli 1. Wraz z zagęszczeniem podziału siatki obliczenia stają się coraz bardziej czasochłonne. Obraz odkształceń głównych dla wspornika E - II dla zagęszczonego, typowego i rozrzedzonego podziału powierzchni został zaprezentowany na rysunku 1. Wszystkie mapy odkształceń głównych dotyczą tego samego elementu przy sile wynoszącej $1300 \mathrm{kN}$ i skali odkształceń od 0 do 30\%o. Porównując ze sobą rysunki 1 a i 1 b można stwierdzić, że dla większych fasetek otrzymano rysy zdecydowanie bardziej rozmyte, mniej szczegółowe obrazy odkształceń.

$\mathrm{Na}$ rysunku 1a widoczne są miejsca wypełnione białym kolorem. Są to fragmenty powierzchni dla których nie ma danych pochodzących z analizy. Jest to skutkiem sposobu przygotowania powierzchni. W zależności od wielkości pola pomiarowego i od przewidywanego podziału powierzchni na fasetki należy dobrać odpowiedni deseń (rozmiar punktów nanoszonych na powierzchnię). W przypadku gdy wewnątrz fasetki znajduje się zbyt dużo elementów o zbyt podobnym do siebie kolorze (Aramis identyfikuje obrazy korzystając z 256 odcieni szarości) system nie rozpoznaje fasetki jako jednoznacznie zdefiniowanego fragmentu powierzchni. 


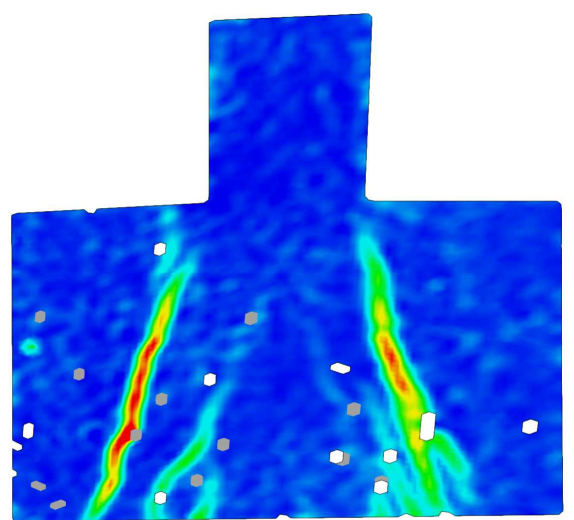

a)

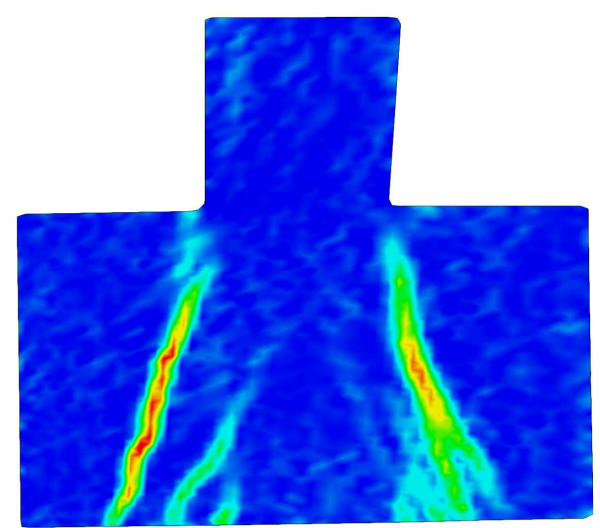

c)

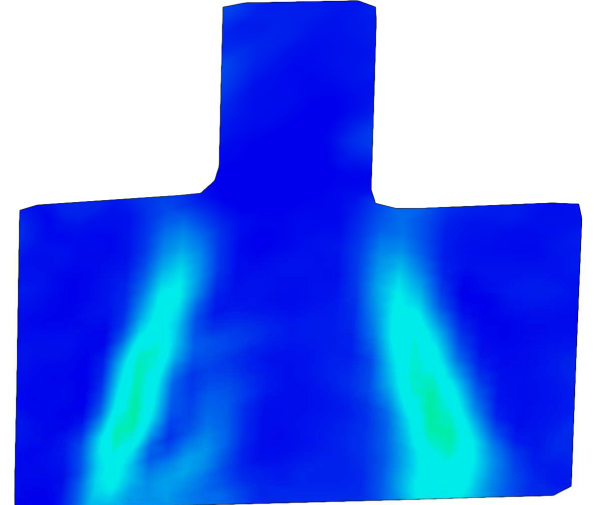

b)

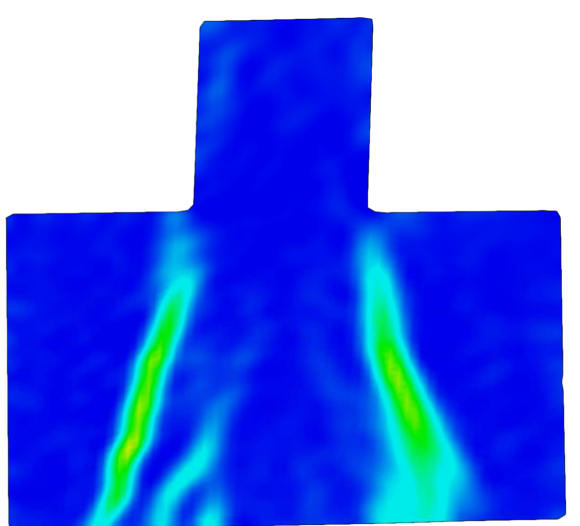

d)

Rys. 1. Mapy odkształceń głównych we wsporniku E - II przy obciążeniu 1300 kN. Powierzchnia podzielona na fasetki a) $15 \times 15$, b) $45 \times 45$, c) $18 \times 18$, d) $18 \times 18$ z podwójnym sąsiedztwem

Fig. 1. Comparison of principal strain maps for corbel $\mathrm{E}-\mathrm{II}$ for load equal to $1300 \mathrm{kN}$. Surface divided into facets a) $15 \times 15$, b) $45 \times 45$, c) $18 \times 18$, d) $18 \times 18$ with double neighborhood

\section{Analiza błędów}

Istotną kwestią wydaje się ustalenie błędu wyznaczenia odkształceń. Ze względu na istotną z wyliczeniem niepewności pomiaru powszechnie stosuje się sprawdzenie szumu pomiarowego. Metodę taką zastosował Kneć [1] oraz Revilock $i$ inni [2]. Sprawdzenie polega na wykonaniu wielu zdjęć powierzchni. Zakłada się, że próbka niepoddana obciążeniu, ani zmianie temperatur powinna wyglądać tak samo. A zatem wszelkie zarejestrowane zmiany długości lub przyrosty odkształceń są błędem pomiaru. Takie podejście poza prostotą wykonania ma jeszcze jedną zaletę. Ustalenie niepewności uwzględnia wszystkie możliwe 
czynniki wpływu dla konkretnego pomiaru. Należy zwrócić uwagę na utrzymanie jednakowych warunków oświetlenia podczas badania.

Celem wyznaczenia błędów pomiaru dla prezentowanych wyników badań wykonano serię 400 pomiarów (800 zdjęć) nieobciążonego wspornika. Na rysunkach 2., 3. i 4. przedstawiono odczyty długości dla wirtualnych baz pomiarowych. Na rysunku 2 porównano wyniki dla ekstensometrów o długości $20 \mathrm{~mm}$ (E20) i $200 \mathrm{~mm}$ (E200). Stwierdzono, że dla dłuższej bazy pomiarowej odczyty wahały się w zakresie od $-0,017 \mathrm{~mm}$ do $+0,011 \mathrm{~mm}$, natomiast dla krótszej od $-0,005 \mathrm{~mm}$ do $+0,012 \mathrm{~mm}$. Na podstawie wyników wykonano analizę statystyczną danych celem wyznaczenia błędów. Zgodnie z teorią błędów pomiaru wyznaczono błędy graniczne dla poszczególnych serii odczytów. Prawdopodobieństwo wystąpienia pomiaru, odstającego od wartości średniej o więcej niż o błąd graniczny wynosi $0,86 \%$. Precyzja wyznaczenia długości odcinków jest na poziomie $\pm 0,010 \mathrm{~mm}$ dla krótszej i $\pm 0,014 \mathrm{~mm}$ dla dłuższej bazy pomiarowej. Jest to dokładność większa niż dla typowej lupy Brinella o powiększeniu 24x, gdzie podziałka elementarna na skali to $0,05 \mathrm{~mm}$.

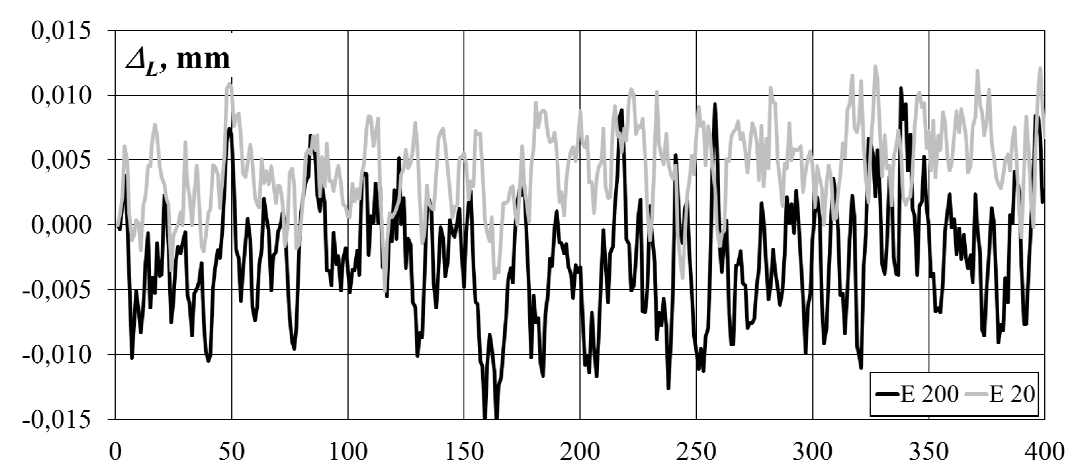

Rys. 2. Zmiana długości wirtualnych baz pomiarowych - element nieobciążony (bazy o długościach $20 \mathrm{~mm}$ - E20 i 200 mm - E200)

Fig. 2. Length change of virtual measuring base specimen without any load (base length $20 \mathrm{~mm}$ - E20 and $200 \mathrm{~mm}$ - E200)

Na rysunku 3. przedstawiono odczyt długości wirtualnych baz pomiarowych o długości około $20 \mathrm{~mm}$ (E1, E2). W części zarejestrowanych etapów pomiaru widać znacznie większe odczyty. Dla uwidocznienia tej obserwacji na rysunku 4 pokazano etapy od 190 do $220 \mathrm{z}$ rozszerzoną skalą pionową. Widać, że odczyty osiągnęły wartość $-0,100 \mathrm{~mm}$, kilkukrotnie przekraczając wartość błędu granicznego pomiaru. Przyczyną takiej sytuacji była zmiana warunków oświetlenia na tej części powierzchni, na której znajdowały się bazy E1 i E2. 


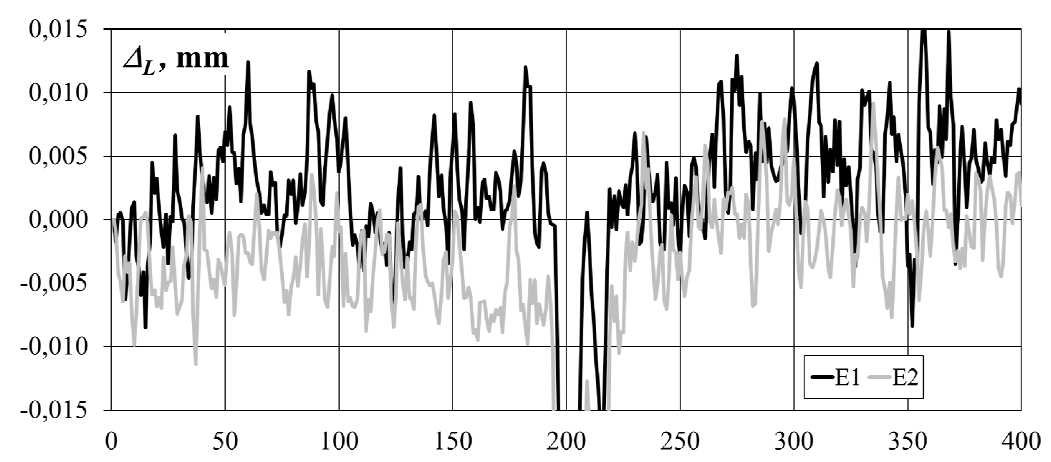

Rys. 3. Zmiana długości wirtualnych baz pomiarowych w strefie, gdzie zostały zmienione warunki oświetleniowe, element nieobciążony

Fig. 3. Length change of virtual measuring base in area where lighting conditions were changed specimen without any load

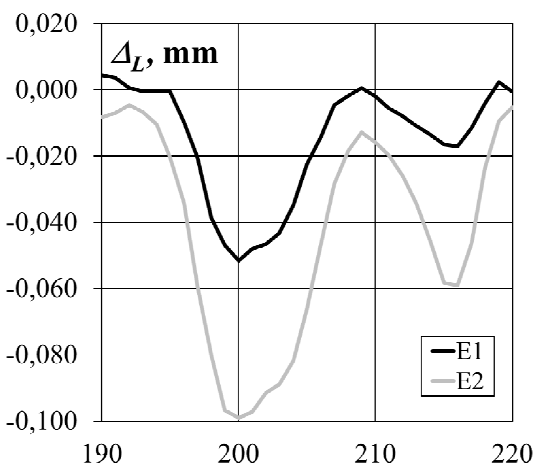

Rys. 4. Zmiana długości wirtualnych baz pomiarowych podczas zmiany warunków oświetlenia bez obciążenia (etapy od 190 do 220)

Fig. 4. Length change of virtual measuring base during lighting conditions were changed without any load (stages from 190 to 220)

Kolejnym zagadnieniem jest dokładność wyznaczenia odkształceń w punktach powierzchni. Na rysunkach 5., 6. i 7. przedstawiono odczyt odkształceń $\varepsilon_{x}$, $\varepsilon_{1}$ i $\varepsilon_{2}$. Błąd graniczny odczytu odkształceń wzdłuż osi $\mathrm{X}$ wynosi $\pm 0,34 \%$ o, natomiast dla odkształceń głównych $\pm 0,59 \%$. O ile wyznaczenie przemieszczeń liniowych można uznać za precyzyjne na potrzeby badania konstrukcji żelbetowych, o tyle dokładność wyznaczenia odkształceń stanowi znaczący procent wartości, przy której spodziewane jest zniszczenie betonu. 


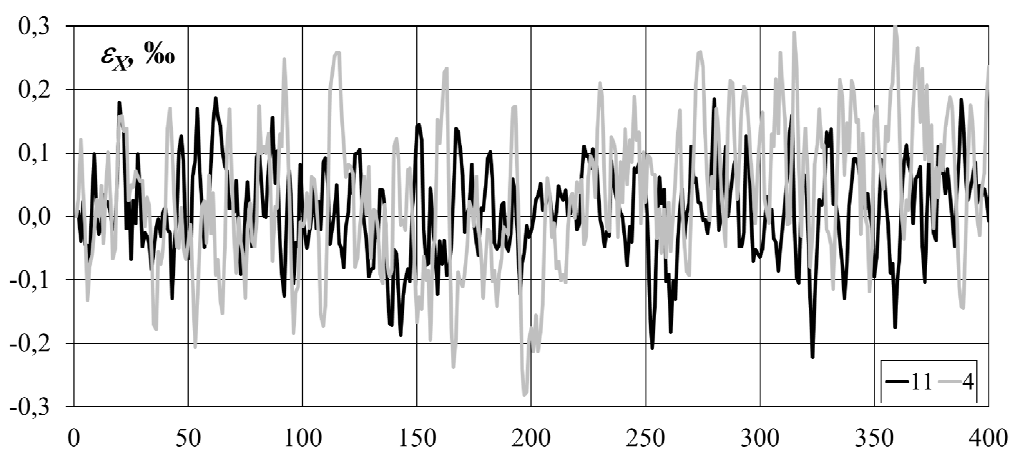

Rys. 5. Zmiana odkształceń $\varepsilon_{x} \mathrm{~W}$ wybranych punktach powierzchni bez obciążenia Fig. 5. Strain $\varepsilon_{x}$ change in chosen points of surface without any load

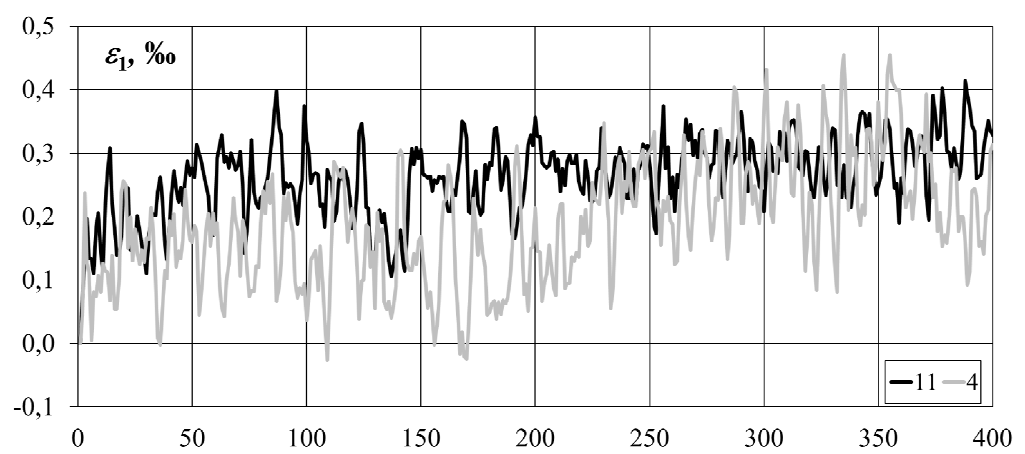

Rys. 6. Zmiana odkształceń głównych $\varepsilon_{1} \mathrm{w}$ wybranych punktach powierzchni bez obciążenia Fig. 6. Principal strain $\varepsilon 1$ change in chosen points of surface without any load

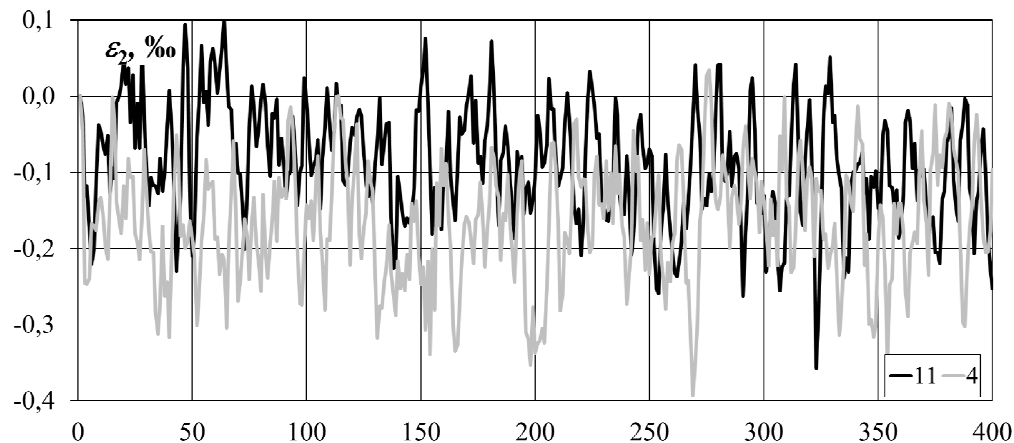

Rys. 7. Zmiana odkształceń głównych $\varepsilon_{2} \mathrm{w}$ wybranych punktach powierzchni bez obciążenia

Fig. 7. Principal strain $\varepsilon_{2}$ change in chosen points of surface without any load 
Algorytmy programu Aramis pozwalają na zwiększenie dokładności wyznaczania odkształceń. Jest to możliwe dzięki zastosowaniu większej liczby punktów obliczeniowych. Dla Aramisa, który stosuje trójkątną siatkę obliczeniową, typowa procedura zakłada wykorzystanie pojedynczego sąsiedztwa (sześciu punktów) dla wyznaczenia odkształceń. Zwiększenie dokładności wymaga zastosowania podwójnego sąsiedztwa (osiemnastu punktów). Ideę sąsiedztwa graficznie zaprezentowano na rys. 8 . Wewnątrz zaciemnionego obszaru oznaczono miejsce, dla którego obliczamy odkształcenia. Wewnątrz strefy oznaczonej kolorem szarym znajdują się punkty konieczne do przeprowadzenia obliczeń.

Na rysunkach 9, 10 i 11 pokazano porównanie odczytów odkształceń $\varepsilon_{x}, \varepsilon_{1}$ i $\varepsilon_{2}$ wybranego punktu obliczanego z uwzględnieniem pojedynczego (11) i podwójnego sąsiedztwa $(11 \mathrm{n}=2)$. Dla $\varepsilon_{x}$ i $\varepsilon_{2}$ nie obserwuje się zwiększenia dokładności (patrz rysunki 9, i 11). Znaczny wzrost precyzji zaobserwowano dla $\varepsilon_{1}$ (patrz rysunek 10).

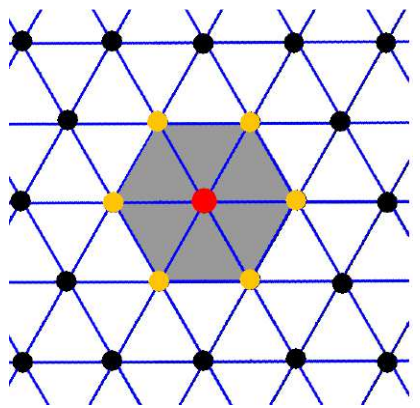

a)

Rys. 8. Wielkość sąsiedztwa przyjmowana do obliczenia odkształceń a) pojedyncze b) podwójne

Fig. 8. Neighborhood size adopted to strain calculation a) single b) double

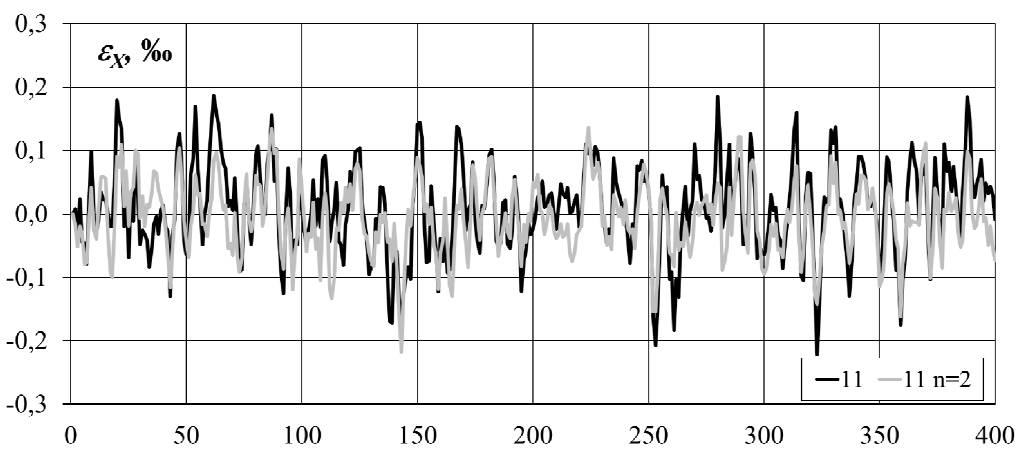

Rys. 9. Porównanie odkształceń $\varepsilon_{x}$ dla pojedynczego (11) i podwójnego sąsiedztwa (11 n=2) punktu bez obciążenia

Fig. 9. Comparison of strain $\varepsilon x$ for single (11) and double (11 n=2) neighborhood without any load 


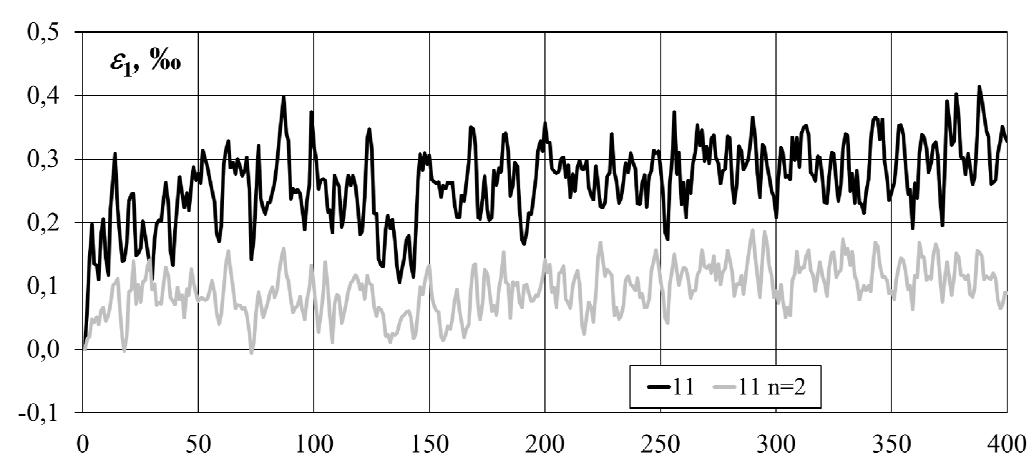

Rys. 10. Porównanie odkształceń głównych $\varepsilon 1$ dla pojedynczego (11) i podwójnego (11 n=2) sąsiedztwa punktu bez obciążenia

Fig. 10. Comparison of principal strain $\varepsilon$ for single (11) and double $(11 \mathrm{n}=2)$ neighborhood

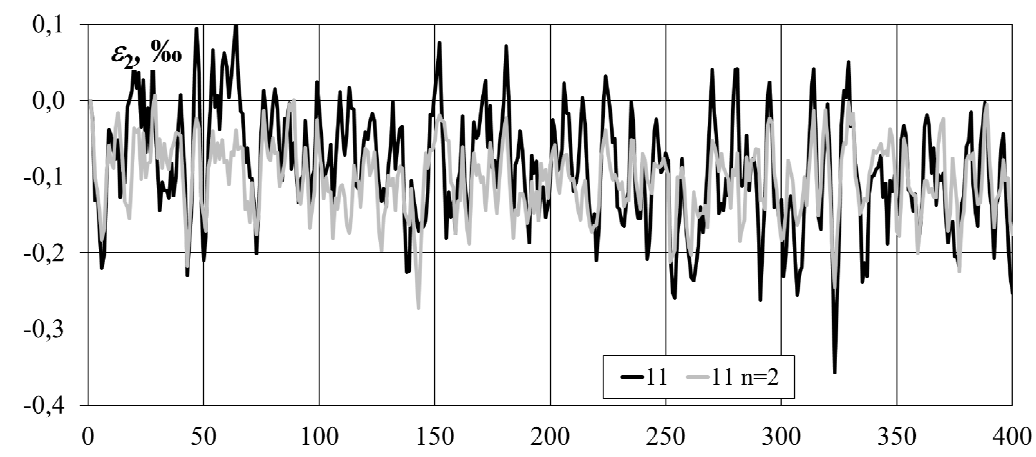

Rys. 11. Porównanie odkształceń głównych $\varepsilon 2$ dla pojedynczego (11) i podwójnego (11 n=2) sąsiedztwa punktu

Fig. 11. Comparison of principal strain $\varepsilon_{2}$ for single (11) and double $(11 \mathrm{n}=2)$ neighborhood

Trzeba jednak zdawać sobie sprawę z konsekwencji zwiększenia dokładności przez powiększenie sąsiedztwa. Większy obszar, potrzebny do wyznaczenia odkształceń, oznacza mniejszą szczegółowość danych. Różnicę widać porównując rysunki 1c (pojedyncze) i 1d (podwójne sąsiedztwo).

Za pomocą systemu Aramis możliwy jest też odczyt odkształceń na zadanej liniowej bazie pomiarowej. Na rysunku 12. przedstawiono wyniki odkształceń dla baz pomiarowych.

Stwierdzono taki sam (co do rzędu wielkości) błąd wyznaczenia długości bazy. Zatem błąd wyznaczania odkształceń będzie tym większy im krótsza baza. Jest to widoczne na omawianym rysunku 12 . Odczyty odkształceń dla bazy o długości $200 \mathrm{~mm}$ (E200) wahają się od $-0,081 \%$ o do $+0,055 \%$, natomiast dla krótszego odcinka (E20) od -0,236\%o do $+0,567 \%$. Błąd graniczny odczytu odkształceń bazy pomiarowej wynosi $\pm 0,07 \%$, a dla $20 \mathrm{~mm} \pm 0,45 \%$. 


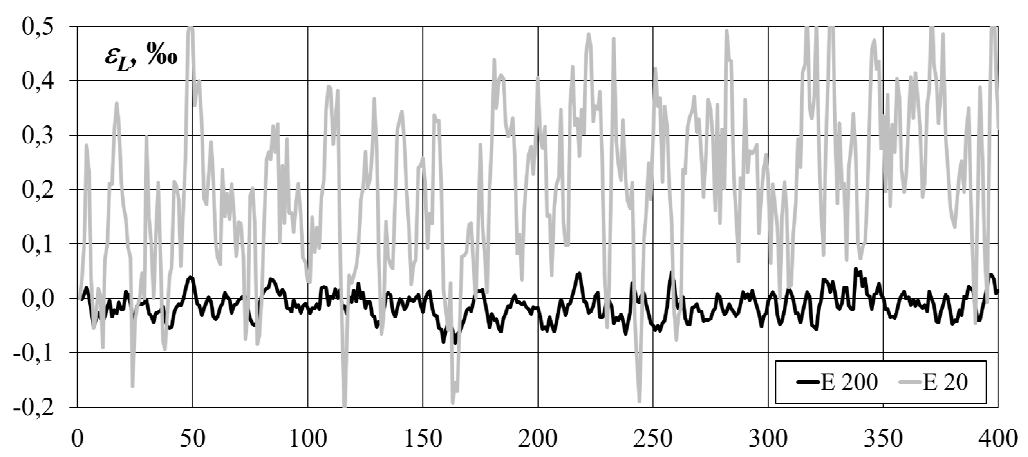

Rys. 12. Porównanie odkształceń na baz pomiarowych liniowych bez obciążenia (bazy o długościach 20 mm - E20 i 200 mm - E200)

Fig. 12. Comparison of strain for linear measuring bases without any load (base $20 \mathrm{~mm}$ and $200 \mathrm{~mm}$ )

\section{Odczyt szerokości rys}

Oczywistą możliwością wykorzystania Aramisa jest pomiar szerokości rozwarcia rys. Poprawny odczyt szerokości rysy nie jest jednak łatwy do określenia. $\mathrm{Na}$ mapach nie są widoczne rysy a jedynie kumulacje odkształceń. Dzieje się tak na skutek uśredniania wyników wewnątrz elementów obliczeniowych - punkty obliczeniowe znajdują się w odległości kilkunastu milimetrów od siebie, więc nie ma możliwości zaobserwowania rysy jako nieciągłości materiału. Wyznaczenie szerokości rozwarcia rysy zostało zaprezentowane na kilku przykładach.

Na rysunku 13b zaprezentowano bazy pomiarowe do wyznaczenia szerokości rys $\mathrm{nr} 2,2$ '. Wstępnie przyjęto, że dla prawidłowego odczytania szerokości rysy pomiaru należy dokonywać poza strefą kumulacji odkształceń (rysa 2). Takie rozwiązanie sugerowane jest przez Goszczyńska i Tworzewska [3]. W innym artykule wydanym przez ośrodek kielecki [4] autorzy stwierdzają dobrą zgodność szerokości rys zmierzonych za pomocą Aramisa i lupką Brinella (stosowano lupkę o podziałce $\pm 0,05 \mathrm{~mm}$ ). Stosując takie podejście zaobserwowano jednak większe szerokości większe szerokości rozwarcia rys w porównaniu z pomiarami wykonanymi tradycyjnie (rysa 2) - patrz rysunek 13a. Stwierdzono zatem, że należy dobrać właściwą długość bazy pomiarowej dla otrzymania miarodajnych wyników. Na podstawie prób zaproponowano bazy pomiarowe (rysa 2'), dla których szerokości rozwarcia są najbardziej zbliżone do pomierzonych tradycyjnie (2 wzrok.).

Dla otrzymania rezultatów najbardziej zbliżonych do pomiaru tradycyjnego (wzrokowego) szukano najbardziej odpowiedniej długości pomiaru. Każdorazowo długość ta była krótsza od całkowitej szerokości kumulacji odkształceń (patrz rys. 13b). Dla prezentowanego przykładu użyto długości referencyjnej równej $12 \mathrm{~mm}$. Jest to odcinek pomiarowy, który nie obejmuje całej strefy kumulacji odkształceń (wynoszącej $42 \mathrm{~mm}$ ). 


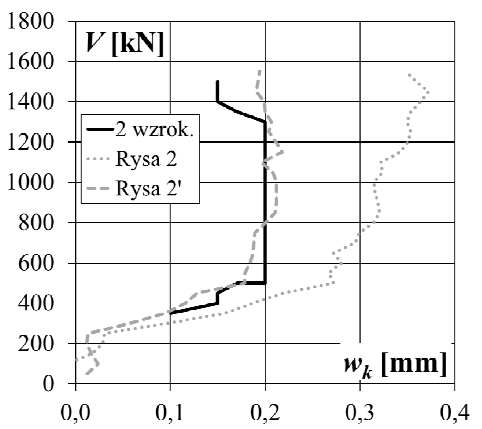

a)

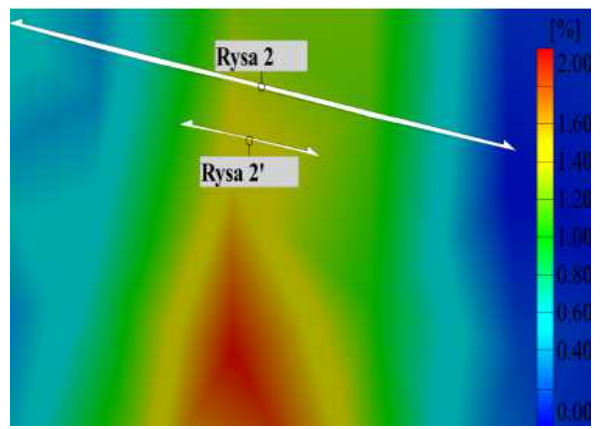

b)

Rys. 13. Rysa nr 2 a) porównanie szerokości rozwarcia zmierzonych tradycyjnie (pomiar wzrokowy -2 wzrok.) i za pomocą systemu Aramis, b) bazy pomiarowe Aramis (Rysa 2 i Rysa 2')

Fig. 13. Crack no. 2 a) comparison of crack widths measured traditionally ( 2 wzrok.) and by Aramis, b) measuring base Aramis (Rysa 2 i Rysa 2')

Dla prawidłowego odczytania szerokości rozwarcia rysy należy dobrać długość referencyjną. Najprostszą metodą jest dopasowanie bazy na podstawie wzrokowych pomiarów szerokości rysy dla kilku wybranych poziomów obciążenia. Na podstawie takich danych można sprawdzić dla jakiej długości pomiaru uzyskiwana jest zgodność między wynikami otrzymanymi z Aramisa a pomiarami tradycyjnymi. Pozostałe wartości otrzymane z systemu będą miarodajne.

Ze względu na różnice w odkształceniach głównych w zależności od przyjętej wielkości siatki obliczeniowej (patrz rys. 1.) zbadano wpływ tej zmiennej na szerokość rys. Początkowo chciano utrzymać taką samą długość i lokalizacje pomiaru. Ostatecznie zdecydowano się na pewne przesunięcie baz względem siebie, ze względu na nieco inny przebieg strefy kumulacji odkształceń w zależności od wielkości fasetek. W zaproponowanej konfiguracji każdy z pomiarów wykonywany jest względem środka symetrii strefy zwiększonych odkształceń. $\mathrm{Na}$ rysunku 14. pokazano porównanie otrzymanych wyników. Szerokości rys 4' p15 i 5' p15 otrzymano na podstawie siatki o wielkości fasetki $15 \times 15$, z dopiskiem p21 dla fasetek $21 \times 21$, natomiast adnotacja p45 oznaczała odniesienie do siatki $45 \times 45$. Wniosek jaki można sformułować jest następujący: czym drobniejsza siatka tym większe rozwarcie rysy otrzymujemy dla bazy o takiej samej długości. Dla utrzymania prawidłowej (porównywalnej z pomiarem tradycyjnym) szerokości rys należy skracać bazę wraz z zagęszczaniem siatki. 


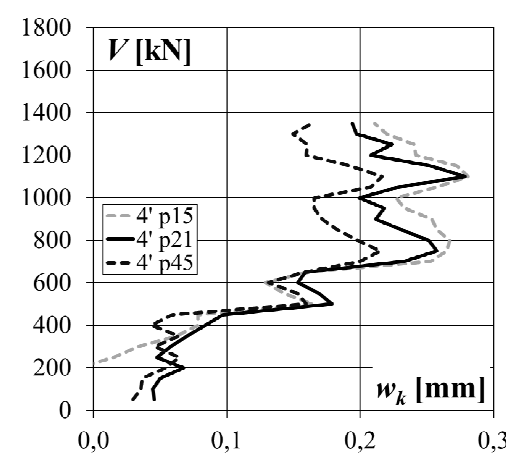

a)

Rys. 14. Wpływ rozmiaru fasetki na szerokości rys a) 4' b) 5', zmierzonych system Aramis

Fig. 14. Influence of the facet size on width of cracks a) 4' b) 5', measured by Aramis system

\section{Podsumowanie}

Przedstawione poniżej wnioski dotyczą niedokładności systemu Aramis, dla pola pomiarowego $1250 \times 1100 \mathrm{~mm}$. Uwzględniają one wszystkie wpływy, które występowały podczas badań. Jest to o tyle istotne, że błędy systemów korelacji obrazów zależne są od niedokładności wyznaczenia punktów na matrycy (położenie w pikselach). A zatem czym większy obszar pomiarowy przypada na każdy piksel mierzonej powierzchni tym błąd (mierzony w $\mathrm{mm}$ ) staje się większy. Teoretyczne rozważania dotyczące błędów systemów cyfrowej korelacji obrazów przedstawiono w [5].

Wyznaczenie przemieszczeń liniowych można uznać za precyzyjne na potrzeby badania konstrukcji żelbetowych. Trzeba zastrzec, że dla prawidłowego, czyli zgodnego z pomiarem wzrokowym, określenia szerokości rozwarcia rys należy dobrać referencyjną długość bazy pomiarowej. Wartość ta może być inna dla każdej z rys w danym zadaniu. Ponadto należy uwzględnić wpływ wielkości fasetek na tę długość.

Dokładność wyznaczenia odkształceń w punktach stanowi istotny procent odkształceń granicznych betonu. Mapa odkształceń składa się z wielu punktów, każdy z nich obarczony jest błędem pomiaru. Pomimo tego można wyciągać wnioski na podstawie obrazu odkształceń, dzięki któremu wiemy w jakich obszarach występuje ściskanie a w jakich rozciąganie, jak wygląda obraz odkształceń głównych. Co do ilościowych danych należy zachować świadomość występujących błędów. Jednocześnie na podstawie zmiany długości czujnika liniowego można obliczyć odkształcenie na długości bazy pomiarowej. Błąd pomiaru jest tym mniejszy im dłuższe bazy zostaną użyte.

Istotny wpływ na dokładność pomiaru ma intensywność oświetlenia powierzchni. Dla uzyskania najlepszych efektów należy prowadzić badania przy możliwie stałych warunkach oświetlenia. Wykonując kilka (kilkanaście) pomia- 
rów dla jednego obciążenia możliwe będzie uśrednienie wyników, co prowadzi do mniejszego błędu pomiaru.

\section{Literatura}

[1] Kneć M.: „Technika cyfrowej korelacji obrazów w analizie deformacji połączeń elementów konstrukcji stosowanych w lotnictwie". Rozprawa doktorska. Politechnika Rzeszowska 2015.

[2] Revilock D.M., Thesken J.C., Schmidt T.E. i Forsythe B.S.: "Three-Dimensional Digital Image Correlation of a Composite Overwrapped Pressure Vessel During Hydrostatic Pressure Test" Raport techniczny wydany przez NASA 2007.

[3] Goszczyńska B., Trąmpczyński W., Tworzewska J., Tworzewski P.: "Doświadczalna analiza odkształceń przestrzennych belek żelbetowych z zastosowaniem skanera optycznego 3D”, Inżynieria i Budownictwo, 2014 s. 156-159.

[4] Goszczyńska B., Tworzewska J.: "Określenie rysy na potrzeby analizy wyników badania procesu powstawania i rozwoju rys w belkach żelbetowych z zastosowaniem systemu Aramis", Przegląd Budowlany, 2014, s. 24-29.

[5] Ajdukiewicz C., Gajewski M., Mossakowski P. „Zastosowanie systemu optycznej korelacji obrazu ,Aramis” do identyfikacji rys w elementach betonowych”, Materiały konferencyjne Transcomp - XIV International Conference Computer Systems Aided Science, Industry and Transport, 2011.

\section{ABOUT INACCURACIES OF DIC SYSTEM}

\section{S u m m a r y}

The aim of the paper is estimating of measuring inaccuracies for Aramis system. Because of issue complexity it is difficult to find general solution. For the application purpose method consists of comparison many photos showing one state of surface is used. In the paper analysis of the inaccuracies for measuring volume $1250 \times 1100 \mathrm{~mm}$ is presented. Dispersion of the results recorded by Aramis system is the value of the measuring error. It is stated that values from strain maps contain error which is significant with respect to ultimate strain of concrete. Simultaneously very good accuracy of the the line segment length change is reported. It causes that observation of crack width is presisly. In the second part of the paper some practical information concern how determined compatibility between crack width measured traditionally and by Aramis are written. Discussion of influence of facet size on crack width is presented.

Keywords: digital image corelation, measuring error, crack width, experimental investigations

Przestano do redakcji: 24.05.2017 r.

Przyjęto do druku: 01.09.2017 r. 